\title{
Observations on some papers presented at the Shanghai forum, October 2010
}

\author{
Alex C. Michalos
}

Published online: 28 May 2011

(C) Springer Science+Business Media B.V. 2011

\begin{abstract}
This paper is a set of comments on papers from the Third Shanghai International Conference on Business Ethics, October 29-30, 2010, Shanghai, China. I would like to thank the organizers of this conference for the opportunity to share some of my observations on some of the papers presented. As a result of some serious health problems, I could not make the conference and engage in the discussions. However, I am glad to be able to make some comments on a subset of the papers that the adjudication committee thought should go into this collection. Some excellent papers were not included in the collection because they did not fit the scope of the Asian Journal of Business Ethics. So nothing in my comments should be regarded as any kind of comment on papers not mentioned here. I hope I can add some value to the good work already displayed in these papers. My comments are presented in the order in which I read the papers.
\end{abstract}

Keywords Financial capital $\cdot$ Business case $\cdot$ Professional ethics $\cdot$ Metaphors · Corporate responsibility $\cdot$ Foreign exchange

\section{Xiaohe Lu}

The aim of this paper is to show how the use of social capital for the production of private wealth was at least partly responsible for the U.S. financial crisis that spread across the globe in 2008 and how the risk of such crises might be avoided in the future with the help of business ethicists and other business stakeholders ensuring that social capital is used to produce for society. In my terms, I would say the final aim is to ensure that social capital is used in the interest of the public good, not only in the interest of the private good of a relatively few individuals.

She showed how Marx's analyses of some of the contradictions in capitalism were played out in the 2008 credit crisis as the world economy moved deep into the

\footnotetext{
A. C. Michalos $(\bowtie)$

Brandon University, 270 18th Street, Brandon, MB, Canada R7A 6A9

e-mail: Michalos@brandonu.ca
} 
stage of financial capital with credit money producing only more credit money, and the real economy of manufactured goods becoming increasingly detached from the financial economy. When I was writing my monograph on Good Taxes (1997), the chemical manufacturing giant DuPont (which for years advertised that it brought us "better things for better living through chemistry") was making more money from DuPont Finance than from DuPont chemists. In earlier financial crises in the 1990s, at least in Canada, the distance between our real and financial economies was such that great decreases in the value of the latter had relatively little impact on the jobs of people in the former, real economy. The 2008 meltdown was much more serious, with jobs disappearing regardless of the relative disconnection between the real and financial economies. Leaders of our federal government and our banks boasted that they managed the crisis much better because, after all, they were just better managers. But analyses by some economists showed that there were relatively fewer job losses in Canada because relatively large numbers of Canadians took advantage of low interest rates and went into debt buying houses. While government and business debt did not increase, household debt did, and for the past few months the Canadian housing bubble has been deflating. "What we have learnt from the US financial crisis" Lu wrote, "reminds us to lay a greater emphasis on making banks and financial institutions manage social capital in the interest of society. Prevention of public servants from becoming social masters is an issue raised by Karl Marx in The Civil War in France." We do not seem to have learned that lesson in Canada yet.

In the 1990s, with many others around the world, I became interested in the Nobel Laureat James Tobin's idea of reducing risky currency speculation by putting a small tax on currency trading. Intuitively, the idea is quite straightforward. If each time a currency trade is made, a tax is levied on it, then the more frequently currency is traded, the more the trader loses to taxation. Thus, some premium is put on fewer trades and trades representing relatively longer-term investments rather than short-term, hot-money, get-rich-quick trades. While mainstream, neo-classical economists and government officials who believe them usually oppose capital controls, many economists recommend them and some countries performed better during global financial crises because of their controls (Michalos 1997, 2000). At one point in the late 1990s, over 500 parliamentarians around the world had endorsed some sort of Tobin-type taxes. Among other things Gordon Brown recommended during the 2008 credit crisis, Tobin-type taxes were high on his list. According to Jacobs (2011, p. 21),

"France's President Nicolas Sarkozy has pledged to use his term as chair of the G-20 to reform the global financial system and curb the speculation that contributed to the economic crisis. At the top of his agenda is an international financial transactions tax (FTT) to fund the global fight against poverty and climate change. . The FTT is an idea whose time has come. It is backed by political leaders, including the presidents of France, Germany, and the previous prime minister of Britain, Tony Blair. . . The Canadian government should reconsider its opposition to the tax, lest Canada be left behind as other countries take the lead in putting their finances back in order."

Although people often say that such a tax could only work if all countries participated, my own view is that it would work if a few major trading countries 
tried it, showed that it does reduce speculation and does at least pay its own way in revenues. Over a dozen years ago, I predicted that the European Union would be the first to bring in such a tax and that it would have the consequences just mentioned. I still think that will happen. Of course, the introduction of such taxes would be but a small step in the direction of the kind of change in financial management envisioned by Professor Lu, but long journeys may begin with such steps.

\section{Daryl Koehn}

The aim of this paper seems to be briefly stated in its very last sentence, i.e.,

“. . .we need to move beyond dogmatic interpretations of capitalism and market behavior and to focus instead on the complicated interplay among a wide array of factors such as conflicts of interest, unintended consequences, risk management, rhetorical hype about technology, regulation by the state, and the evisceration of the idea of corporate professional responsibility".

I think this sentence is true and Professor Koehn provides plenty of supporting evidence for her views concerning each of the "factors" listed in it. I hope her remark that ". . .CSR appears in some respects to be significantly inversely related to ethical behavior by companies" is only true of a minority of companies, but I have no evidence for this hope. While she does not use the phrase "business case for business ethics" or talk about the counter-productivity of making such cases, I think she may be sympathetic to my view when she wrote that "Overly focused on an overriding goal or 'telos' of profit-maximization, executives become desensitized to any other possible obligations they may have".

Briefly and generally, the business case for corporate social responsibility (CSR) is simply the thesis that being morally good is materially good for business. In other places, I have referred to this as the BC thesis (Michalos 2011) and I have argued that it is the worst argument possible for business ethics because it makes ethics subservient to material gain and puts the whole institution of morality into jeopardy (Michalos 1995). As Cicero observed in the first century BCE, if one's primary interest is in material gain, then when there is no material gain in an activity (e.g., doing what is morally right or good) or more material gain in an exactly opposite activity (e.g., doing what is morally wrong or evil), one will not prefer the morally right or good activity (Michalos 2008a). Since the moral battle for the hearts and minds of business people is to get them to do what is morally good or right even when there is no material advantage in it, the BC thesis is counter-productive. It amounts to feeding business people's most narrow self-interests when we should be feeding their most broad other-interests.

There is, of course, a long philosophic tradition of propping up morality by showing that one's moral virtue contributes to one's self-interest in various ways, for example, because God will reward you in this life or some other, or it will bring advantageous Karma sooner or later, or others will find you more likable or, as Plato and Aristotle argued, you will often enough find pleasure in moral actions properly performed. Plato used the metaphor of pleasure as "a handmaid of virtue", emphasizing its subservience and Aristotle ridiculed those who suggested that a 
person might be happy while being tortured on the rack. Like most of his contemporary Greeks (and probably ours), he thought that pleasure was important for happiness, but not that for the sake of which one should pursue moral virtue or excellence in any form (Michalos and Robinson 2011).

For the ancients as well as for all others since their time it is difficult to convince people that they ought to do the right thing morally speaking because it is the right thing to do. If their primary interest lies elsewhere, it seems that the best one can do is to try to show how doing the right thing morally speaking somehow or other serves their primary interest. So ethicists emulate Saint Paul (who lived about 400 years after Plato and Aristotle) becoming "all things to all people so that by all means a few will be saved". I do not have a nice solution to this very old and difficult problem, but I think it is important to remind ourselves of it whenever we are inclined to make the business case for business people doing the right thing morally speaking.

It may help to characterize management as "professional" as Koehn does insofar as it has similarities with other professions, but maybe not. One of the problems I have with the written codes of ethics of professionals is that they typically include a statement about duties to their client being of paramount concern (Michalos 1979). She claimed that "Professional doctors, lawyers or engineers often must say 'no' to would be clients when these clients ask for some service that is not consonant with the essence of the professional's stated goal". Maybe so, but often enough doctors, lawyers, engineers and accountants literally sell out to clients because, after all, private profit is also among many professionals' goals. In the dispute between the Ethyl Corporation and the government of Canada over the fuel additive known as MMT, the mistrust between the scientists and engineers funded by Ethyl and those funded by automobile makers was so great that research papers published in the $S A E$ Technical Paper Series routinely listed their sponsors, e.g., references began "(Ethyl) Brown. . .; (General Motors) Benson. . .; (Ethyl) Meffert. . .; (Ford) Hubbard. ..” (Michalos 2008b).

Deborah Poff has emphasized that academic researchers are in an inherent conflict of interest insofar as they are rewarded for publishing papers that may or may not serve the public interest, but will probably serve their own. In her words,

“. . . the contemporary professor is by virtue of her or his employment in a university in a constant and inherent conflict of interest. Socrates did not want to be paid to profess. He understood that with such compensation came constraint and potential if not actual conflict of interest. The contemporary professor rarely lives a monastic life. She or he receives financial reward, status and esteem, external rewards and recognitions, invitations and opportunities based upon her or his success in research creation and production. . While public institutions may serve the common good, the academic faculty member is not solely engaged in serving this good but also in serving her or his own goals, aspirations and objects" (Poff 2011).

Contrary to Reich (2007) but consistent with Michalos (2010), Koehn wrote, "In addition to reemphasizing fiduciary duties, we need seriously to rethink to what extent large modern corporations can really be regulated by the passage of laws". I also agree with her remark that "the average citizen and business school student has 
been served a steady diet of implausible claims about how markets actually work". In Michalos (1997), I presented apparently compelling arguments borrowed from others showing that the efficient market hypothesis concerning financial markets was demonstrably false, but I have not seen any rush by mainstream economists to abandon it. I gather from Koehn's quotations from Greenspan that he would probably still not abandon it.

\section{Christopher Michaelson}

The aim of the paper seems to be to show that metaphors from literature ("humanistic works of art and culture"), which the author claims appear in "canonical texts" (e.g., Machiavelli's The Prince, Sun Tzu's The Art of War), can describe and prescribe behavior generally and economic behavior in particular that is helpful in promoting values for "a more sustainable capitalism". Metaphors have been and are enormously important for science, art and civilized life in general. Their impacts have been studied from a variety of perspectives, and have been notoriously understudied by students of business ethics.

Since the beginning of the Journal of Business Ethics in 1982, I have tried to encourage the exploration of commercial activity by social scientists. At the beginning, like many other fields of study, the field of business ethics was dominated by philosophers but I was certain that the field was ripe for exploration by all kinds of social scientists. Anyone who reviews the output of articles published in JOBE over the past 29 years will see immediately that while we have succeeded in thoroughly integrating the social sciences into our field, we have failed to make a dent on explorations of literature and the arts.

My partner, Deborah Poff, has been the editor and an active collaborator in the development of the Journal since the beginning and has always been a stronger proponent than I have been for bringing in more contributions by humanists and artists. In this, she was certainly right. Had I listened more carefully and reacted more enthusiastically, we might have had much more success than we have had so far. In any event, it is good to see papers calling for more comprehensive explorations of all the levers that motivate and actually move human beings to action.

Michaelson is sensitive to the difficulties, complexities really, of selecting canonical texts. If one recalls the impact of Dickens's and Zola's stories of the lives of working people as the industrial revolution grew across Europe, and the later stories of Steinbeck and others in North America, their importance becomes immediately obvious. Like the fathers of several of my working class friends, my father died just about the time when he had achieved some economic security for himself and his family. I was 15 years old. As a result of that experience, one of the most powerful metaphors in my own life has been a remark in Arthur Miller's Death of a Salesman. When Willy Loman's refrigerator breaks down, adding to his current miseries, he bursts out "They time those things. So when you finish paying for them, they're all used up." A few weeks ago I was reading of Oliver Stone's shock when he discovered that the greedy trader (Gordon Gekko) of his hit film of the 1980s, Wall Street, was regarded as a hero by many people rather than as the heartless thug Stone imagined him to be. 
I don't know what most people thought of Machiavelli's would-be successful prince. He did not think of all princes as thugs, although he gave plenty of examples of successful thugs. When Michaelson reminded us of Sun Tzu's insistence on a leader having wisdom, benevolence and subtlety, I was reminded of Machiavelli's insistence on leaders having the capacity to be a fox and a lion in different circumstances.

I think the paper would be strengthened by some attention to the possibility that one person's good metaphor might be another's bad metaphor, and that an artist's intention to produce a particular sort of reaction in his or her audience might produce quite the opposite effect. Remember Aristotle's analysis of works of art based on artists' intentions, as well as the contents and consequences of the completed works.

\section{G. J. Rossouw}

This paper describes part of a global survey of business ethics. It will be good to see the details of the total sample, including the methodology and all players, when they appear in a special issue of the Journal of Business Ethics.

Using "the term corporate responsibility as a generic term that includes the economic, social and environmental responsibility of business", the author reported that "it is fair to conclude that the global financial crisis of 2008 and the resulting global economic crisis of 2009 had a very definite impact on [the] elevation of the priority of the Ethics of Capitalism, the Ethics of Finance, and Corporate Responsibility in the field of Business Ethics on a global scale". Among other things, Professor Rossouw commented on the fact that "in some regions of the world. . .[CSR] is no longer perceived as a part of the field of Business Ethics, but as a field on its own". We got some suggestion of this trend in the Journal of Business Ethics a short while ago when we discovered that the work load of our Section Editor for Corporate Responsibility (Adam Lindgreen) was much larger than that of any other Section Editor. Therefore, in the last year we divided that Section into three, namely, Corporate Responsibility: Theoretical/Qualitative Issues (Lindgreen Section Editor), Corporate Responsibility: Quantitative Issues (Joelle Vanhamme Section Editor) and Corporate Governance and Sustainability (Thomas Clarke Section Editor).

Rossouw is worried about "the disconnect between Business Ethics and CSR" because he believes (correctly I think) that "ethical questions about the moral status and moral responsibilities of the corporation get neglected" when the focus becomes CSR. Sometimes he refers to the "ethical dimension" as the "normative dimension", but I think it would be helpful to use only the one phrase "ethical dimension" because there are non-ethical norms and normative rules, e.g., norms and rules about looking both ways before crossing a street, wearing white at night, driving on the right side of the road, washing hands before eating, and so on. While some people claim that good corporate leaders should be guided by value-free economic theories, Bernie Hodgson, my late friend and for many years Section Editor for Philosophical Foundations on JOBE argued persuasively in Hodgson (2001) that neo-classical economic theory is not only not value-free but is basically a flawed moral theory. 
Rossouw also worries about "the divorce of CSR from the field of Business Ethics" implying "a divorce from the philosophic tradition which has always been one of the distinct contributors to the field of Business Ethics". Since I have always tried to attract non-philosophers into the discussions about business ethics, on the assumption that bringing people together from diverse disciplinary backgrounds, with different experiences and interests would be beneficial for our discussions and our field of research, I would be disappointed if the "divorce" from philosophy occurred. Of course, I know that there has certainly been a "separation" if not an outright nasty "divorce" in many universities insofar as there are often business ethics courses mainly taken by liberal arts students and taught in philosophy departments, and business ethics courses mainly taken by commerce or business students and taught in commerce or business departments. I think it is unfortunate, but I have no control over it. To some extent this division of labor in universities is just another expression of the way most of us were taught to live in disciplinary silos by people who lived in disciplinary silos because they were taught by the same kinds of people for as long as anyone can remember. Early on in my professional career I was struck by the fact that in the faculty club economists ate lunch with economists, philosophers ate with philosophers and so on for most of the faculty. Except for one table that attracted only faculty members who grumbled about our poor working conditions and good-for-nothing administrators, there was little evidence of cross-disciplinary cultivation of any sort.

The last worry of Rossouw that I would like to mention is his concern that "the internal and external ethical obligations of corporations" will not be adequately attended to if the CSR and business ethics divorce continues. In his view, "the internal organizational integrity of corporations" is very important and likely to be neglected if the focus of attention is Corporate Social Responsibility. I agree that this is worrisome, and as Daryl Koehn emphasizes in her paper, it is a good reason to follow the Europeans who abandon CSR in favor of Corporate Responsibility. I suppose none of us would be willing to argue that such a nominal change would be sufficient to bring about the substantial change of focus we all would like to see, but it would probably be a step in the right direction.

\title{
Peter Buytaert
}

Among many interesting things, the central themes of this paper are given in the following paragraph.

\begin{abstract}
"Globally, CSR needs to find its sustainable development via the recognition of tangible benefits that CSR will bring to organizations and their stakeholders. The less tangible but likely most important benefit lies to our opinion in the continual improved leadership and management quality emerging from organizations investing in CSR. We argue that wise leadership and better management quality will automatically lead to an organization's cost optimizations, increased brand value and sustainable growth via aligned and continued ethically correct and socially responsible decisions and actions."
\end{abstract}

This clearly seems to be an affirmation of the business case for CSR, about which I have said enough already. He makes his case by listing some specific benefits, e.g., 
"improved quality of leadership and reduced employee turnover. . .substantial HR cost reductions. . competitive differentiation appealing to a growing consumer market. . .taking a lead in regulatory compliance. . .increased brand value. . .directly increasing equity valuations". Of course these are all desirable achievements for a commercial organization. The trouble is, as suggested earlier, in some circumstances an organization might obtain even larger benefits with manipulative or coercive leadership, maybe not in the long run, but as Keynes said, "in the long run we are all dead".

The "China market" provides an impressive list of tangible "motivational drivers" undermining CSR, e.g., the "market offers exceptional growth opportunities. . . stakeholders' request for companies to also deliver on these growth expectations. . . inadequate regulations or lack of enforcement".

The unique market conditions raise difficult questions, e.g., "When outsourcing for lower wages in China. . ., how large a wage differential is acceptable?. . Should a buyer company demand that a supplier observes applicable national and local law?".

Finally, the author recommends policies to address the special problems in China, e.g., "an independent and secure whistleblower channel. . .effective execution and enforcement of laws and regulations. . .[focusing efforts in a few areas like] pharmaceuticals and food. . Education of "value based leadership"'. While all of these policies are reasonable strategies for increasing compliance with ethical or social norms, such compliance may be quite independent of moral virtue. Maybe commercial conditions in China and other countries are such that doing the right thing for the wrong reasons is the best one can hope to do. Like many others, I hope not.

\section{Wei Yang and Kit-Chun Joanna Lam}

This paper deals with a topic in business ethics that has been significantly understudied. The central problem is the economic, social and ethical implications of the massive amount of foreign exchange reserves held in China. Several factors are mentioned that tend to appreciate the value of Renminbi (RMB), e.g., the growth of the Chinese economy, the increases in balance of payments surpluses and the differences in the economies of China, the European Union and the USA. The continued appreciation of the RMB will lead to a decrease in the value of foreign exchange reserves, mostly resulting from depreciation of the US dollar. In turn, this value reduction in reserves will lead to "a massive opportunity cost for China as these funds can be used to support education and improve health care of the poor". Appreciation of the RMB will "increase the international price of China's export", reducing market share and profits, especially on labor intensive industries. "The lower profit and even bankruptcy will cause companies to reduce production and employment, resulting in an increase in unemployment of low-skilled workers." As the RMB increases, more foreign capital will flow into China, leading to a rapid "increase in property prices" and a reduced standard of living for "common people". In fact, "The real income of the rich actually increases more than the poor because of appreciation."

Faced with all these likely consequences, reducing the standard of living of those who are most vulnerable while those who are most powerful continue to flourish, the 
authors recommend policies to "alleviate the problems", e.g., some "fiscal intervention to reduce the adverse distribution effect of the appreciation of the RMB. . .increase public construction. . the internal market should be expanded. . . the composition of foreign exchange reserves should be re-balanced to increase the weight of other major currencies. . .use of the RMB as an international currency should be promoted".

The authors delivered on their promise "to illustrate the inter-relationship between economics and ethics". They made a good case for students of economics and business generally to be well-trained and sensitized to the ethical impact of economic policies. I hope that others will be provoked by the analyses in this paper to push the research frontier of inter-relationships still farther.

\section{References}

Hodgson, B. (2001). Economics as moral science. Berlin: Springer.

Jacobs, J. (2011) Taxing international finance: will Canada be left behind, The CCPA Monitor, March, p. 21 .

Michalos, A. C. (1979). The loyal agent's argument. In T. Beachamp \& N. Bowie (Eds.), Ethical Theory and Business (pp. 247-253). Englewood Cliffs: Prentic-Hall.

Michalos, A. C. (1995). A pragmatic approach to business ethics. Thousand Oaks: SAGE Publishers.

Michalos, A. C. (1997). Good taxes: The case for taxing foreign currency exchange and other financial transactions. Toronto: Science for Peace and Dundern Press.

Michalos, A.C. (2000) A handful of sand in the wheels of financial speculation. Paper presented at the Conference on New Rules for the New Millennium, sponsored by Mani Tesi, Florence, Italy, March $18-19$.

Michalos, A. C. (2008a). Ancient observations on business ethics: Middle East meets West. Journal of Business Ethics, 79(1-2), 9-19.

Michalos, A. C. (2008b). Trade barriers to the public good: Free trade and environmental protection. Montreal and Kingston: McGill-Queen's University Press.

Michalos, A. C. (2010). The monster of supercapitalism. Journal of Business Ethics, 91, 37-48.

Michalos, A.C. (2011) The business case for asserting the business case for business ethics. Journal of Business Ethics (in press).

Michalos, A.C. and S.R. Robinson (2011) The good life: eighth century to third century BCE. In: K.C. Land, A.C. Michalos and M.J. Sirgy (Eds.), Handbook of Social Indicators and Quality of Life Research. Dordrecht: Springer (in press).

Poff, D.C. (2011) Research funding and academic freedom. In: R. Chadwick (ed.), Encyclopedia of Applied Ethics, Elsevier, Dordrecht (in press).

Reich, R. B. (2007). Supercapitalism: The transformation of business, democracy, and everyday life. New York: Knopf. 